\title{
Effect of Boron Foliar Application on Yield and Quality of Some Sunflower (Helianthus annuus L.) Cultivars
}

\author{
Bahaa El-Din Mekki \\ Field Crops Research Department, National Research Centre, P.O. BOX 12622, Dokki, Giza, Egypt
}

\begin{abstract}
This study was carried out in the greenhouse of the National Research Center, Dokki, Giza, Egypt, in order to investigate the effect of foliar application of boron $(0,300$ and $600 \mathrm{ppm} \mathrm{B})$ as boric acid $\left(\mathrm{H}_{3} \mathrm{BO}_{3}, 17 \% \mathrm{~B}\right)$ on the yield and yield components and also the seed quality of two sunflower cultivars (Sakha-53 and Giza-102). B application at a rate of 600 ppm produced the highest values of seed yield/plant (g), head diameter $(\mathrm{cm})$, number of seeds/head, weight of 1,000 seed (g), percentage of oil (\%) and oil yield/plant (g) of both cultivars. Seed yield/plant increased by $26.85 \%$ and $34.81 \%$ with increasing B concentration from $300 \mathrm{ppm}$ and $600 \mathrm{ppm}$ as compared to control plants, respectively. The results indicated that application of 300 ppm B resulted in an increase of palmitic, stearic and oleic acids as compared to the treatment with 600 ppm B and control plants. However, the linoleic acid increased gradually with increasing B up to $600 \mathrm{ppm}$. Such increases were estimated by $8.72 \%$ and $7.19 \%$ over the control plants or the treatment sprayed with $300 \mathrm{ppm} \mathrm{B}$, respectively. The highest oleic and linoleic acids percentages (52.71\% and 36.05\%, respectively) were obtained from Sakha-53 cultivar with 300 ppm B foliar application, while the lowest lenolenic acid percentage (2.01\%) was obtained at $600 \mathrm{ppm}$ B. The highest content of gluatmine, isoleucine and arginine (9.61, 3.97 and $3.97 \mathrm{mg} / 100 \mathrm{~g}$ dry weight) was obtained from Sakha-53 cultivar, followed by Giza-102 at a rate of 600 ppm foliar application of B. It can be concluded that B plays a vital role for increasing the productivity and quality of sunflower plants, especially when grown under B deficient soil.
\end{abstract}

Key words: Sunflower, B, seed yield, fatty acids, amino acids.

\section{Introduction}

Sunflower (Helianthus annuus L.) is one of the most important oilseed crops containing high quality edible oil, and it is easy to cultivate and grow in different conditions and soils. Moreover, sunflower oil has excellent nutritional properties, and sunflower seed contains high oil content ranging from 35\%-48\% with some types yielding up to 50\%, 20\%-27\% protein and high percentage of polyunsaturated fatty acids (60\%), including oleic acid (16.0\%) and linoleic acid (72.5\%), which control cholesterol in blood $[1,2]$. One of the most important issues about increase of crop yield and improving the quality of agricultural products is balanced plant nutrition. Boron (B) deficiency among microelements is the most harmful to the crop after iron and zinc [3]. A main function of

Corresponding author: Bahaa El-Din Mekki, Ph.D., research fields: field crops productivity and physiology.
B is correlated to cell wall formation, nitrogen fixation, sugar transportation, phenol, nucleic acid, carbohydrate and indole acetic acid (IAA) metabolism, and membrane stability. Flower retention and pollen formation and germination also are affected by B [4, 5]. Brighenti and Castro [6] demonstrated that seed yield and oil yield were increased by B consumption, and stated that B consumption increased the pollen fertility. Thus, with increase of the number of filled grain, yield is increased.

Sunflower has been found to be particularly sensitive to B deficiency and is sometimes used as an indicator for assessing available B in soils [7]. Yield and the component in vegetative and reproductive stages of sunflower may both be affected positively and negatively by $\mathrm{B}$ depending upon the dose used as a fertilizer. In B deficient soils, foliar applied B significantly enhanced the vegetative and reproductive dry matter of plants. B application improved the total 
dry matter three times in B deficient plants than in B sufficient plants [8]. Thus, balanced B nutrition is also indispensable for optimum crop growth, development and achene yield of sunflower. B is important for various plant physiological functions, such as nucleic acid, carbohydrates, protein, IAA and phenol metabolism, cell wall synthesis and structure, membrane integrity and functions, as well as sugar translocation [9]. B deficiencies occur over a much wider range of soils and crops in comparison to deficiencies of any other micronutrient elements [10].

Therefore, the main objectives of this study were to: (1) study the response of two open pollinated sunflower cultivars to foliar application of B under B deficient soil; (2) evaluate the productivity and seed quality of some sunflower cultivars with B foliar application; (3) determine if B that was applied as foliar spray to B deficient sunflower plants is taken up and utilized for improving the productivity of sunflower.

\section{Materials and Methods}

A pot experiments were carried out during two successive summer seasons 2013 and 2014 in the greenhouse of the National Research Centre, Dokki, Giza, Egypt, in order to investigate the effect of foliar application of $\mathrm{B}$ as boric acid $\left(\mathrm{H}_{3} \mathrm{BO}_{3}, 17 \% \mathrm{~B}\right)(0,300$ and $600 \mathrm{ppm}$ ) on the yield and yield components as well as the seed quality of two open pollinated sunflower cultivars (Sakha-53 and Giza-102). The analysis of physical and chemical properties of soil was carried according to the methods described by Jackson [11] and the data were presented in Table 1.

Seeds of two open pollinated sunflower cultivars (Sakha-53 and Giza-102), mainly obtained from the Oil Crops Department, Agricultural Research Center, Giza, Egypt, were sown in plastic pots $(40 \mathrm{~cm}$ diameter and $40 \mathrm{~cm}$ depth) filled with $20 \mathrm{~kg}$ clay-loam soil on May 15 during two successive summer seasons of 2013 and 2014. Pots were arranged in factorial experiment in complete randomized design with five replicates. Thinning was practiced at $30 \mathrm{~d}$ after planting
Table 1 Physical and chemical properties of the soil (average of two seasons).

\begin{tabular}{ll}
\hline Properties & Value \\
\hline Soil texture & Clay-loam \\
$\mathrm{pH}$ & 7.87 \\
$\mathrm{EC}(\mathrm{dS} / \mathrm{m})$ & 0.18 \\
Organic matter (\%) & 2.89 \\
Calcium carbonate $(\%)$ & 0.72 \\
Available N (ppm) & 55.00 \\
Available P (ppm) & 5.50 \\
Available K (meq/L) & 50.70 \\
Available B (ppm) & 0.71 \\
$\mathrm{Cl}^{-}($meq/L) & 2.15 \\
$\mathrm{Na}^{+}(\mathrm{meq} / \mathrm{L})$ & 3.81 \\
$\mathrm{Ca}^{++}(\mathrm{meq} / \mathrm{L})$ & 0.70 \\
$\mathrm{Mg}^{++}(\mathrm{meq} / \mathrm{L})$ & 2.40 \\
\hline
\end{tabular}

to leave one plant each pot until harvest. Phosphorus and potassium fertilizers were added before sowing at a rate of 6.0/pot calcium super phosphate $\left(15.5 \% \mathrm{P}_{2} \mathrm{O}_{5}\right)$ and $3.0 \mathrm{~g} /$ pot of potassium sulfate $\left(48 \%-50 \% \mathrm{~K}_{2} \mathrm{O}\right)$, respectively. Nitrogen fertilizer was applied as two equal portions at a rate of $0.60 \mathrm{~g} /$ pot for each in the form of ammonium nitrate $(33.5 \% \mathrm{~N})$ at $30 \mathrm{~d}$ and $60 \mathrm{~d}$ after planting. While, B foliar application (0, 300 and $600 \mathrm{ppm}$ ) was applied twice, the 1 st time was at $45 \mathrm{~d}$ after planting and the 2nd was after two weeks later.

At harvest, plants were uprooted from each pot, sundried for one week and then the parameters of yield and yield components were determined, i.e., seed yield/plant (g), head diameter ( $\mathrm{cm})$, number of seeds/head and weight of 1,000 seed (g). Seed oil content (\%) was determined by using Soxhlet units and petroleum ether $\left(40-60^{\circ} \mathrm{C}\right)$ as a solvent according to AOCS [12]. Oil yield (g/plant) was calculated by multiplying the seed yield/plant (g) by oil\%. Fatty acid composition was also determined using methyl etherification and gas-liquid chromatography by Central Lab of National Research Centre, Dokki, Giza, Egypt.

\subsection{Determination of Total Amino Acids (HCl-Hydrolyzed)}

The protein ( $25 \mathrm{mg}$ or about $0.1 \mathrm{~g}$ dry matter) of defatted sunflower meal was hydrolyzed with $10 \mathrm{~mL} 6$ 
$\mathrm{N} \mathrm{HCl}$ in a sealed tube [13]. The solution (e.g., with a mixture of dry ice/ethanol) was frozen and evacuated with a vacuum pump (approximately $6.5 \mathrm{~Pa}$ (0.01 mbar)). The hydrolysis tube was then closed by melting the glass with a suitable gas burner and hydrolyzed in an oven with a uniform temperature distribution of $110{ }^{\circ} \mathrm{C}$ for $24 \mathrm{~h}$ in order to create well reproducible hydrolysis conditions (an oven with air circulation is recommend). The tube was cooled down in an ice-bath after hydrolysis. Afterwards, the solution should be centrifuged in order to precipitate insoluble components. The supernatant of the centrifuged solution was taken and evaporated at approximately $40{ }^{\circ} \mathrm{C}$ in a rotary evaporator, and then dissolved with approximately $1 \mathrm{~mL}$ distilled water and evaporated once again in order to remove traces of acid. The sample was dissolved with 1-2 $\mathrm{mL}$ of the sample-diluting buffer. The sample was then ready for analysis with Eppendorff LC3000 (Germany) amino acid analyzer under the following conditions: flow rate $(0.2 \mathrm{~mL} / \mathrm{min})$, pressure of buffer (0-50 bars), pressure of reagent (0-150 bars) and reaction temperature $\left(123^{\circ} \mathrm{C}\right)$.

\subsection{Statistical Analysis}

All obtained data of yield and its components were statistically analyzed by using MSTATC program according to Snedecor and Cochran [14] and the combined analysis was according to Steel and Torrie [15].

\section{Results and Discussion}

\subsection{Effect of Foliar Application with B on Yield and Yield Components of Two Sunflower Cultivars}

Data presented in Table 2 indicated that in general the differences between two sunflower cultivars (Sakha-53 and Giza-102) were insignificant in most yield traits, except seed yield/plant and oil yield/plant were significantly differed. However, application of B up to $600 \mathrm{ppm}$ significantly increased seed weight/plant, weight of 1,000 seed, oil\% and oil yield in both sunflower cultivars (Sakha-53 and Giza-102). On the other hand, head diameter and number of seeds per head were not significantly affected by $B$ application. Seed yield/plant was increased by $26.85 \%$ and $34.81 \%$ with increasing B concentration from 300 ppm and $600 \mathrm{ppm}$ compared to the untreated plants, respectively. These results were supported by the findings of Al-Amery et al. [16], who pointed that seed yields also were increased with increasing in $\mathrm{B}$ application, and this may also be through a prolonged

Table 2 Yield and yield components of two sunflower cultivars as influenced by B foliar application (average of two seasons 2013 and 2014).

\begin{tabular}{|c|c|c|c|c|c|c|c|}
\hline Cultivars & $\begin{array}{l}\mathrm{B} \\
(\mathrm{ppm})\end{array}$ & $\begin{array}{l}\text { Head diameter } \\
(\mathrm{cm})\end{array}$ & $\begin{array}{l}\text { Seed yield/plant } \\
\text { (g) }\end{array}$ & $\begin{array}{l}\text { No. of seeds } \\
\text { /head }\end{array}$ & $\begin{array}{l}\text { Weight of } \\
1,000 \text { seed (g) }\end{array}$ & Oil\% & $\begin{array}{l}\begin{array}{l}\text { Oil yield } \\
\text { (g/plant) }\end{array} \\
\end{array}$ \\
\hline & 0 & 10.13 & 16.33 & 462.55 & 20.50 & 24.16 & 3.95 \\
\hline \multirow[t]{2}{*}{ Sakha-53 } & 300 & 10.38 & 16.34 & 627.41 & 28.90 & 27.03 & 4.42 \\
\hline & 600 & 11.00 & 18.13 & 692.65 & 41.60 & 32.22 & 5.84 \\
\hline \multirow[t]{2}{*}{ Mean } & & 10.83 & 16.93 & 594.20 & 30.30 & 27.80 & 4.71 \\
\hline & 0 & 9.63 & 8.03 & 354.67 & 28.70 & 26.28 & 2.11 \\
\hline \multirow[t]{2}{*}{ Giza-102 } & 300 & 10.38 & 14.56 & 532.50 & 28.20 & 28.77 & 4.19 \\
\hline & 600 & 10.50 & 14.71 & 747.79 & 30.40 & 29.02 & 4.27 \\
\hline \multirow[t]{2}{*}{ Mean } & & 10.17 & 12.43 & 544.98 & 29.10 & 28.02 & 3.48 \\
\hline & 0 & 9.88 & 12.18 & 408.61 & 24.60 & 25.22 & 3.07 \\
\hline \multirow[t]{3}{*}{ Mean values of B } & 300 & 10.88 & 15.45 & 579.96 & 28.50 & 27.90 & 4.31 \\
\hline & 600 & 10.75 & 16.42 & 720.22 & 36.00 & 30.62 & 5.03 \\
\hline & $\mathrm{Cv}$. & NS & 2.07 & NS & NS & NS & 0.58 \\
\hline \multirow[t]{2}{*}{$\mathrm{LSD}_{0.05}$} & B & NS & 2.53 & 100.08 & 0.83 & 0.80 & 0.71 \\
\hline & Cv. $\times$ B & NS & 3.58 & NS & NS & 1.13 & NS \\
\hline
\end{tabular}

Cv. $\times$ B: the least significant difference values between cultivars and boron at 0.05 level; NS: not significant. 
photosynthetic capacity during flowering and seed set or through improved partitioning from the increased biomass. Al-Amery et al. [16] also reported that the biggest effect of applied B resulted in an increase in seed yield, and this is partly may be due to the decrease in seed sterility. The results show that it is agronomically useful to apply B to sunflower at the start of flowering, and more consistent effects are achieved at application of B. Data presented in Table 2 also indicated that number of seeds/head, weight of 1,000 seed, oil percentage as well as the oil yield (g/plant) was significantly increased with increasing B concentration up to $600 \mathrm{ppm}$. These increases were estimated by $76.26 \%, 46.34 \%$ and $63.84 \%$, respectively. These results are in agreement with those obtained by Al-Amery et al. [16] and Tahir et al. [17], who pointed that seed yield of sunflower crop was increased linearly in response to B, and $200 \mathrm{mg} / \mathrm{L} \mathrm{B}$ and $250 \mathrm{mg} / \mathrm{L} \quad$ B applications gave significant increases in yield compared to the control.

In both cultivars, application of $600 \mathrm{ppm} B$ resulted in the highest values of seed weight/plant, head diameter, number of seeds/head, weight of 1,000 seed, oil\% and oil yield (g/plant). These results were in accordance with Oyinlola [7], who reported that head diameter was increased by applying B. Similarly, Renukadevi and Savithri [18] and Tahir et al. [19] found that $\mathrm{B}$ application significantly increased the head diameter. This may be because of $\mathrm{B}$ role in cell elongation, photosynthesis, translocation of sugars and transpiration. Number of seeds/head significantly increased with increasing levels and varying sources of B. Shaker and Mohammed [20] reported that the interaction of genotypes and B levels showed significant effect on head diameter and number of seeds/head. However, Renukadevi and Savithri [18] found that foliar spray of $\mathrm{B}$ at $0.3 \%$ and $0.2 \%$ concentration were on par with soil applied B at the rate of $1.5 \mathrm{~kg} / \mathrm{ha}$, and it was found superior than soil applied B at the rate of $1.0 \mathrm{~kg} / \mathrm{ha}$. However, the highest seed yield/plant (18.13 g) and oil percentage
(32.22\%) was obtained from Sakha-53 cultivar in combination with $600 \mathrm{ppm} \mathrm{B}$. The increase in seed yield and oil\% in Shaka-53 with applying 600 ppm B may be due to the increase of other yield components in Sakha-53 under high B concentration than the other sunflower cultivar. Similar results were also reported by Renukadevi and Savithri [18], who pointed that application of $\mathrm{B}$ had brought out a tremendous increase in the oil yield of sunflower. Soil application of $2.0 \mathrm{~kg} \mathrm{~B} / \mathrm{ha}$ recorded the highest oil yield. The significant increase in oil yield might be due to the increase in oil content by soil application of $2.0 \mathrm{~kg}$ $\mathrm{B} / \mathrm{ha}$. Also, sunflower has been found to be particularly sensitive to B deficiency and is sometimes used as an indicator for assessing available B in soils $[7,16]$. Although $B$ is essential for crop growth and can be applied to meet crop demands, harmful effects can be induced by excessive applications during early phases of growth [7, 21]. Yield and its component in vegetative and reproductive stages of sunflower may both be affected positively and negatively by $\mathrm{B}$ depending upon the dose used as a fertilizer. Shaker and Mohammed [20] reported that application of 3 $\mathrm{mg} / \mathrm{L}$ of B fertilizer significantly led to an increase in head diameter, number of seeds/head, weight of 1,000 seed and seed yield by $4.88 \%, 9.39 \%, 16.15 \%$ and $8.65 \%$ for spring season and by 5.21\%, 8.67\%, $16.67 \%$ and $8.46 \%$ for autumn season, respectively, as compared to check treatment. These findings are in agreement with those obtained by Renukadevi and Savithri [18], who reported that application B increased significantly the 100 achene weight of sunflower. Vyakaranahal et al. [22] also reported significant affect on 100 achene weight. This may be due to the $\mathrm{B}$ role in translocation of photoassimilates from vegetative to reproductive parts of sunflower. The stimulatory effect of B on sunflower plant may be due to its role in enhancing metabolic process and improving development of pollen tube. In B deficient soils, foliar applied B significantly enhanced the vegetative and reproductive dry matter of plants. B 
application improved the total dry matter three times in B deficient plants than in B sufficient plants [8]. Thus, balanced B nutrition is also indispensable for optimum crop growth, development and seed yield of sunflower.

\subsection{Effect of Foliar Application with B on Fatty Acids Composition of Two Sunflower Cultivars}

Data presented in Table 3 indicated that the two sunflower cultivars in general produced the same values of saturated and unsaturated fatty acids. Data in Table 3 also indicated that application of 300 ppm B resulted in an increase of palmitic, stearic and oleic acids in comparison to untreated plant or the treatment with $600 \mathrm{ppm}$ B. However, the linoleic acid was increased gradually with increasing B up to $600 \mathrm{ppm}$. Such increases were estimated by $8.72 \%$ and $7.19 \%$ over the control plants or the treatment sprayed with 300 ppm B, respectively. Linolenic acid seems to be the same values and it was not affected by applying B. The highest oleic and linoleic acids percentages (52.71\% and 36.05\%) were obtained from Sakha-53 cultivars with $300 \mathrm{ppm}$ B foliar application, while the lowest lenolenic acid percentage (2.01\%) was obtained with the same sunflower cultivar in combination with 600 ppm B. Higher oleic acid and lower linolenic acid are desirable traits for oil stability and long-term shelf storage for industrial and processing purposes, but higher linolenic acids (essential polyunsaturated) are desirable for human nutrition. Hydrogenation of polyunsaturated fatty acids, such as linolenic acid, leads to trans-isomers, which are associated with increased incidence of heart disease [23]. However, monounsaturated fatty acids, such as oleic acid, are less susceptible to oxidative changes during refining, storage and frying. Consequently, the food industry is becoming increasingly interested in producing sunflower seed with high content of oleic acid and low linoleic and linolenic acids [24]. Crop fertilized with adequate nitrogen resulted in comparatively greater accumulation of protein in seeds, thereby hindering a satisfactory availability of carbohydrates for polymerization into fatty acids and thus leading to lower content of oil in the seed $[25,26]$.

\subsection{Effect of Foliar Application with B on Amino Acids Composition of Two Sunflower Cultivars}

Concerning the effect of $\mathrm{B}$ foliar application on amino acids composition, data presented in Table 4 indicated that there are more differences in all values of amino acids under low or high B concentrations. Aspartic acid was high in untreated plants compared to treatment with higher B concentrations (300 ppm and $600 \mathrm{ppm}$ ), and glutamic, alannine, isoleucine and arginine acids also had the same trends. Only application of 600 ppm B increased the amino acid tyrosine compared to untreated plants and treatment with

Table 3 Effect of B foliar application on fatty acids composition (\%) of two sunflower cultivars.

\begin{tabular}{lllllll}
\hline \multirow{2}{*}{ Cultivars } & \multirow{2}{*}{$\mathrm{B}(\mathrm{ppm})$} & \multicolumn{5}{c}{ Fatty acids (\%) } \\
\cline { 3 - 7 } & & Palmitic C16:0 & Stearic C18:0 & Oleic C18:1 & Linoleic C18:2 & Linolenic C18:3 \\
\hline \multirow{3}{*}{ Sakha-53 } & 0 & 6.49 & 5.06 & 46.55 & 32.04 & 2.24 \\
& 300 & 7.50 & 3.87 & 52.71 & 33.84 & 2.08 \\
\hline Mean & 600 & 6.54 & 3.68 & 49.43 & 35.53 & 2.01 \\
\hline \multirow{3}{*}{ Giza-102 } & 0 & 6.84 & 4.20 & 49.56 & 33.80 & 2.11 \\
& 300 & 7.15 & 3.84 & 48.46 & 32.93 & 2.31 \\
\hline Mean & 600 & 6.18 & 3.11 & 51.06 & 36.05 & 2.56 \\
\hline \multirow{3}{*}{ Mean values of B } & & 5.61 & 3.32 & 51.12 & 34.58 & 2.10 \\
& 300 & 6.72 & 3.72 & 49.69 & 34.26 & 2.33 \\
\hline
\end{tabular}


Table 4 Effect of $B$ foliar application on amino acids composition of two sunflower cultivars.

\begin{tabular}{|c|c|c|c|c|c|c|}
\hline \multirow{3}{*}{ Amino acids } & \multicolumn{6}{|c|}{ Content of amino acids (g/100 dry weight) } \\
\hline & \multicolumn{3}{|c|}{ Sakha-53 } & \multicolumn{3}{|c|}{ Giza-102 } \\
\hline & 0 ppm B & 300 ppm B & 600 ppm B & 0 ppm B & 300 ppm B & 600 ppm B \\
\hline Aspartic acid & 2.72 & 1.93 & 1.91 & 2.02 & 1.82 & 2.00 \\
\hline Thironine & 1.07 & 0.69 & 0.74 & 0.76 & 0.69 & 0.76 \\
\hline Serine & 1.63 & 1.04 & 1.17 & 1.15 & 1.03 & 1.15 \\
\hline Gluatmic acid & 9.61 & 6.66 & 7.04 & 6.89 & 6.77 & 7.38 \\
\hline Alanine & 4.31 & 3.07 & 3.35 & 3.17 & 3.05 & 3.30 \\
\hline Valine & 1.63 & 1.23 & 1.42 & 1.30 & 1.38 & 1.43 \\
\hline Methionine & 0.55 & 0.53 & 0.69 & 0.50 & 0.41 & 0.57 \\
\hline Isoleucine & 3.97 & 3.05 & 3.39 & 3.21 & 3.02 & 3.31 \\
\hline Leucine & 0.72 & 0.52 & 0.67 & 0.54 & 0.57 & 0.60 \\
\hline Tyrosine & 3.27 & 2.49 & 3.48 & 2.70 & 2.94 & 3.06 \\
\hline Histidine & 1.36 & 0.85 & 1.03 & 1.02 & 0.36 & 1.04 \\
\hline Lycine & 1.74 & 1.16 & 1.27 & 1.24 & 1.13 & 1.21 \\
\hline $\mathrm{NH}_{4}$ & 2.91 & 2.65 & 2.26 & 2.64 & 2.47 & 2.46 \\
\hline Arginine & 3.97 & 2.68 & 3.15 & 3.43 & 3.21 & 3.20 \\
\hline
\end{tabular}

300 ppm B. It may be due to change in the nitrogen metabolism and absorption of $\mathrm{B}$ deficient plants associated with an inadequate supply of this element [27]. These results confirm that of Sauchelli [28], who reported that $\mathrm{B}$ is involved in the synthesis of protein. $\mathrm{B}$ is known to play a role in ion absorption, IAA and carbohydrates metabolism, translocation of sugars and seed development, and its deficiency may affect all these processes [29]. Reduced supply of B in sunflower has also been reported to result from the decrease in release of sucrose and amino acids from plant parts, which ultimately reduces the efficiency on dry mass accumulation or achene yield [30].

Data presented in Table 4 also showed the interaction between two sunflower cultivars and B concentrations. The highest values of gluatmic, isoleucine and arginine (9.61, 3.97 and $3.97 \mathrm{mg} / 100 \mathrm{~g}$ dry weight, respectively) was obtained from untreated Sakha-53 cultivar plants, followed by Giza-102 with 600 ppm B application (7.38 mg/100 g dry weight). Recently, it was found that foliar B application improved seed protein and seed oleic fatty acid [31, 32]. Previous research showed that there was a positive relationship between soil $\mathrm{B}$ and seed protein and oleic acid, suggesting an indirect role of B in seed composition [33]. Other research showed that foliar B application increased soybean seed protein and oleic acid concentrations [32, 34].

\section{Conclusions}

From the above results, it can be concluded that in both sunflower cultivars, application of $600 \mathrm{ppm} \mathrm{B}$ resulted in an increase of seed weight/plant, oil\% and oil yield (g/plant). Also, application of $300 \mathrm{ppm}$ of B as foliar spray resulted in an increase of palmitic, stearic and oleic acids in comparison to untreated plant or the treatment with $600 \mathrm{ppm}$ B. However, the linoleic acid was increased gradually with increasing B up to $600 \mathrm{ppm}$. B foliar application also improved the amino acids contents, only application of $600 \mathrm{ppm}$ $\mathrm{B}$ increased the amino acid tyrosine compared to untreated plants or 300 ppm B. Gluatmic, isoleucine and arginine were increased in untreated Sakha-53 cultivar plants, followed by Giza-102 treated with 600 ppm B.

\section{References}

[1] Patra, P., Pati, B. K., Ghosh, G. K., Mura, S. S., and Saha, A. 2013. "Effect of Biofertilizers and Sulphur on Growth, Yield and Oil Content of Hybrid Sunflower (Helianthus annuus L.) in a Typical Lateritic Soil.” Open Access Scientific Reports 2: 603.

[2] Amirian, S., Golparvar, A. R., and Majd-Nassiri, B. 2013. 
"Character Association, Regression and Path Analysis in Sunflower (Helianthus annuus L.) Hybrids.” Technical Journal of Engineering and Applied Sciences 3 (24): 3640-3.

[3] Arabporian, P., Madani, H., and Sinak, J. M. 2014. "Effects of Micro Elements Spraying on Some Traits in the Safflower (Carthamus tinctorius L.)." Bulletin of Environment, Pharmacology and Life Sciences 3 (3): 228-32.

[4] Farzanian, M., Yarnia, M., Javanshir, A., and Tarinejhad, A. R. 2010. "Effects of Microelement Application Methods on Seed Yield Components in Alestar Sunflower Hybrid.” Journal of Food, Agriculture and Environment 8 (3-4): 305-8.

[5] Wimmer, M. A., and Eichert, T. 2013. "Review: Mechanisms for Boron Deficiency-Mediated Changes in Plant Water Relations.” Plant Science 203-204: 25-32.

[6] Brighenti, A. M., and Castro, C. 2008. "Boron Foliar Application on Sunflower (Helianthus annuus L.) Associated with Herbicides.” Helia 31 (48): 127-36.

[7] Oyinlola, E. Y. 2007. "Effect of Boron Fertilizer on Yield and Oil Content of Three Sunflower Cultivars in the Nigerian Savanna.” Journal of Agronomy 6 (3): 421-6.

[8] Asad, A., Blamey, F. P. C., and Edwards, D. G. 2003. "Effects of Boron Foliar Applications on Vegetative and Reproductive Growth of Sunflower.” Ann. Bot. 92 (4): 565-70.

[9] Goldbach, H. E., Yu, Q., Wingender, R., Schulz, M., Wimmer, M., Findeklee, P., and Baluka, F. 2001. "Rapid Response Reactions of Roots to Boron Deprivation.” Journal of Plant Nutrition and Soil Science 164 (2): 173-81.

[10] Yan, X., Wu, P., Ling, H., Xu, G., Xu, F., and Hang, Q. 2006. "Plant Nutriomics in China: An Overview." Annal. Botany 98: 473-82.

[11] Jackson, M. L. 1970. Soil Chemical Analysis. Englewood Cliffs, NJ: Prentice-Hall.

[12] American Oil Chemists Society (AOCS). 1982. Official and Tentative Methods of American Oil Chemists Society. Illinois, USA: AOCS.

[13] Bailey, J. L. 1967. Techniques in Protein Chemistry, 2nd ed.. Amsterdam: Elsevier Publishing Co..

[14] Snedecor, G. W., and Cochran, W. G. 1980. Statistical Methods, 7th ed.. Iowa, USA: Iowa State University Press.

[15] Steel, R. G. D., and Torrie, J. H. 1960. "Principles Procedures of Statistics.” Biometrische Zeitschrift 4 (3): 207-8.

[16] Al-Amery, M., Hamza, J. H., and Fuller, M. P. 2011. "Effect of Boron Foliar Application on Reproductive Growth of Sunflower (Helianthus annuus L.).” International Journal of Agronomy doi:10.1155/2011/230712.
[17] Tahir, M., Younas-Ishaq, M., Sheikh, A. A., Naeem, M., and Rehman, A. 2014. "Effect of Boron on Yield and Quality of Sunflower under Agro-Ecological Conditions of Faisalabad (Pakistan).” Sci. Agric. 7 (1): 19-24.

[18] Renukadevi, A., and Savithri, P. 2003. "Sunflower (Helianthus annuus) Oil Yield and Quality as Influenced by Boron Application.” Madras Agric. J. 91: 74-6.

[19] Tahir, M., Ashraf, S., and Ibrahim, M. 2013. "Effect of Foliar Application of Boron on Yield and Quality of Sunflower (Helianthus annuus L.).” Crop and Environment 4 (1): 23-7.

[20] Shaker, A. T., and Mohammed, S. A. 2011. "Effect of Different Levels and Timing of Boron Foliar Application on Growth, Yield and Quality of Sunflower Genotypes (Helianthus annuus L.).” Mesopotamia J. of Agric. 39 (3): 16-25.

[21] Shorrocks, V. M. 1997. "The Occurrence and Correction of Boron Deficiency.” Plant and Soil 193 (1): 121-48.

[22] Vyakaranahal, B. S., Shekharagouda, M., Patil, S. A., Prabhakar, A. S., and Giriraj, K. 2001. "Effects of Planting Date and Chemicals (TIBA and Boron) Spray on Seed Yield, Its Attributes and Quality of Single and Three-Way Cross Sunflower Hybrids during Different Seasons.” Seed Res. 29 (2): 127-35.

[23] Rakow, G., and McGregor, D. I. 1973. “Opportunities and Problems in Modification of Levels of Rapeseed C18 Un-saturated Fatty Acid.” Journal of the American Oil Chemists Society 50 (10): 400-3.

[24] Rahman, S. M., Kinoshita, T., Anai, T., and Takagi, Y. 2001. "Combining Ability in Loci for High Oleic and Low Linolenic Acids in Soybean.” Crop Science 41 (1): 26-9.

[25] Singh, S. P., Singh, P. P., and Singh, V. 1988. "Studies on Yield and Yield Attributes in Sunflower (Helianthus annuus L.) Varieties in Relation to Nitrogen Fertilization.” Indian J. Agric. Res. 22: 31-5.

[26] Parameswari, Y. S., Srinivas, A., and Moguloju, M. 2012. "Yield and Oil Content of Sunflower (Helianthus annuus L.) as Influenced by Nitrogen and Boron Nutrition.” Crop Res. 44 (3): 311-3.

[27] Osman, S. E. M., Abdulla, F. E., Harb, O. M. S., Shaaban, M. M., Abou El-Nour, Z. A. A., and El-Saady, A. M. 2005. "Boron Foliar Fertilization Increases Nitrogen Fertilization Efficiency and Improves Yield and Quality of Wheat Plants Grown under Sandy Soil Condition.” Egypt. J. Agric. Res. 2: 323-47.

[28] Sauchelli, V. 1969. Trace Element in Agriculture. New York: Van Nostrand Reinhold Company, 84-8.

[29] Cakmak, I., and Römheld, V. 1997. "Boron Deficiency-Induced Impairments of Cellular Functions in Plants.” Plant Soil 193 (1): 71-83.

[30] Cakmak, I., Kurz, H., and Marschner, H. 1995. "Short-Term Effects of Boron, Germanium and High 


\section{(Helianthus annuus L.) Cultivars}

Light Intensity on Membrane Permeability in Boron Deficient Leaves of Sunflower.” Physiol. Plant. 95 (1): 11-8.

[31] Bellaloui, N. 2011. "Effect of Water Stress and Foliar Boron Application on Seed Protein, Oil, Fatty Acids and Nitrogen Metabolism in Soybean.” American Journal of Plant Sciences 2 (5): 692-701.

[32] Bellaloui, N., Reddy, K. N., Gillen, A. M., and Abel, C. A. 2010. "Nitrogen Metabolism and Seed Composition as Influenced by Foliar Boron Application in Soybean.”
Plant and Soil 336 (1): 143-55.

[33] Bellaloui, N., Hanks, J. E., Fisher, D. K., and Mengistu, A. 2009. "Soybean Seed Composition Is Influenced by Within-Field Variability in Soil Nutrients.” Crop Management 8 (1). doi: 10.1094/CM-2009-1203-01-RS.

[34] Bellaloui, N., Abbas, H. K., Gillen, A. M., and Abel, C. A. 2009. "Effect of Glyphosate-Boron Application on Seed Composition and Nitrogen Metabolism in Glyphosate-Resistant Soybean.” Journal of Agriculture and Food Chemistry 57 (19): 9050-6. 